\title{
Amino Acid Derivative of Calix[4]arene as Schiff base for Sensing of Copper(II)
}

\author{
MANSOURE KHANPOUR ${ }^{1}$, SAEED TAGHVAEI- GANJALI ${ }^{1}$ and REZA ZADMARD *2 \\ 1'Department of Chemistry, Islamic Azad University, North Tehran Branch, \\ P.O. Box: 15875-598, Tehran, Iran, \\ ${ }^{2}$ Chemistry and Chemical Engineering Research Center of Iran, Tehran, IRAN \\ ${ }^{*}$ Corresponding author E-mail: zadmard@ ccerci.ac.ir \\ http://dx.doi.org/10.13005/ojc/330132
}

(Received: December 22, 2016; Accepted: January 25, 2017)

\begin{abstract}
A new amino acid calix[4]arene derivative (5) has been designed, synthesized, characterized with different methods such as HRMS, NMR and FTIR. Our result shows that molecular receptor (5) is more proper for recognizing copper ion than other metal ions. In this paper we have developed a new sensor material for common ions such as copper at low concentration.
\end{abstract}

Keywords: Calixarenes, Schiff bases, Cations.

\section{INTRODUCTION}

Calixarenes are cyclic oligomer which have been applied as ionic and molecular recognition in the past years ${ }^{1}$.

The Calixarene chemists have highly noticed selective proteins, anionic or cationic sensing by changing in quenching effect on fluorescence as a result of its relative ease in addition to high sensitivity and selectivity2,3.

The development of chemosensors for recognizing copper ions has attracted a great deal of interest thanks to its vital role in chemical and biological systems $\mathrm{s}^{4,5}$. Disproportionate amounts of copper ions could possibly result in neurodegenerative diseases and amyotrophiclateral sclerosis ${ }^{6}$. Different Methods such as UV, near infrared and emission spectroscopies were developed for sensing of copper ions using and sensing mechanisms engaging photoinduced electron transfer, fluorescence resonance energy transfer, internal charge transfer, nanotechnology and other photophysical properties which are compatible with the analysis of $\mathrm{Cu}^{2+}$ in biological systems ${ }^{7}$.

It is extremely popular that calixarens can convert to other conformations very fast ${ }^{8}$. 
If the desired function is protein or cationic and anionic recognition, the molecular receptor which has been synthesized, have a prudent balance between flexibility and rigidity. So that it can interact with the different guests. Due to the rigid Calix[4] arene platform and its small cavity, it is not able to accommodating different guest. Calixarenes macrocycle could be modified by functionalization at their upper or the lower rim? .

Most reported chemosensors for copper ions contain the attachment of fluorophore units to the macrocyclic or chelating scaffolds. Among famous macrocyclic frameworks, calix[4]arenes are known to be highly useful building for achieving ionic and molecular recognition ${ }^{10}$, possibly because of their preorganized cavity and facile modifiability.

Schiff bases (imines) are also known to serve as good chelating sites for metal ions ${ }^{11}$. Hence, a molecular probe that has a calixarene scaffold, fluorescence moiety and a Schiff base substructure seems to be worth examining for recognizing metal ions $^{12}$.

Here we explain the synthesis of new Schiffbase calix[4]arene receptor with various functional units for the identification of copper ion in acetonitrile solution.

\section{MATERIALS AND METHODS}

We have used commercial quality solvents and reagents. All cation solutions were prepared from their perchlorate salts and solution of $\mathrm{Cu}^{+}$was also provided from Cul salt.

${ }^{1} \mathrm{H},{ }^{13} \mathrm{C}$ NMR spectra were recorded on a Bruker Avance spectrometer at 500 and 125 $\mathrm{MHz}$ using $\mathrm{CDCl}_{3}$ with TMS reference. In order to record infrared spectra, a Galaxy series FT-IR 5000 spectrophotometer was applied. The melting points were measured by using of a Buchi B-545 apparatus (uncorrected). A Qstare ERSI-q- TOF was used to recording of High resolution mass spectra (HRMS). Florescence spectra were recorded on JASCO FP6500 .

\section{Synthesis}

Compounds (1-3) were prepared based on the literature methods $[13,14]$. The synthesis of other compounds (4-5) was done by adjusting known synthetic procedures.

25,26,27-Tripropoxy-28-[(3-(4-formylphenoxy)propoxy)]-5,11,17,23tetra (tertbutyl)calix[4]arene $\left(4, \mathrm{C}_{63} \mathrm{H}_{84} \mathrm{O}_{6}\right)$

$p$-hydroxybenzaldehyde $0.23 \mathrm{~g}(1.92 \mathrm{mmol})$ and a mixture of $3,0.9 \mathrm{~g}(1 \mathrm{mmol})$ and $\mathrm{K}_{2} \mathrm{CO}_{3}, 0.43$

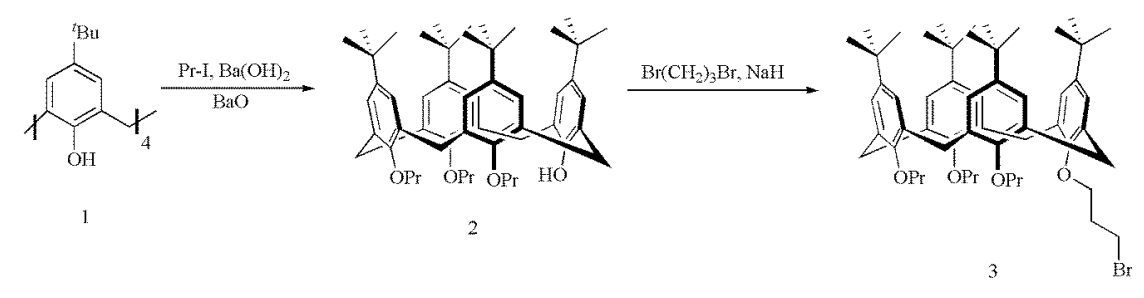

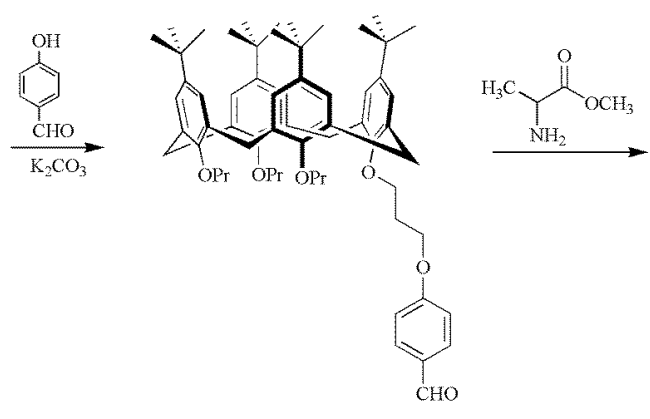

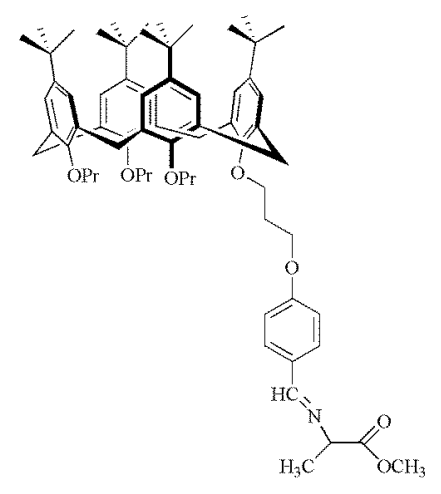

Fig. 1: Synthetic route of 5 


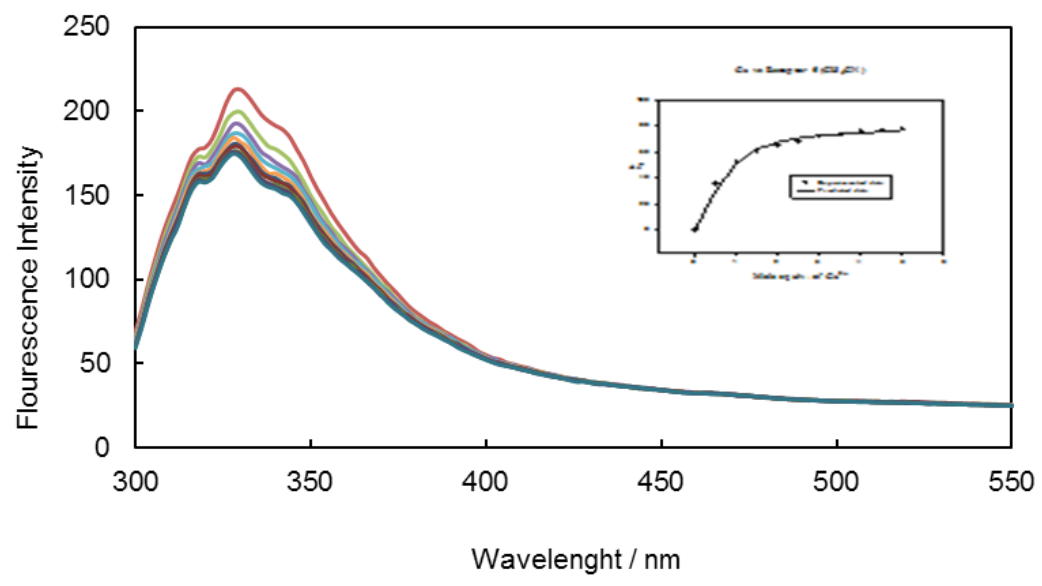

Fig. 2: Changes in fluorescence intensity of $5(40 \mu \mathrm{M})$ in $A C N$ in presence of $\mathrm{Cu}^{2+}(0-16.7 \mu \mathrm{M})$ and resulting titration curve

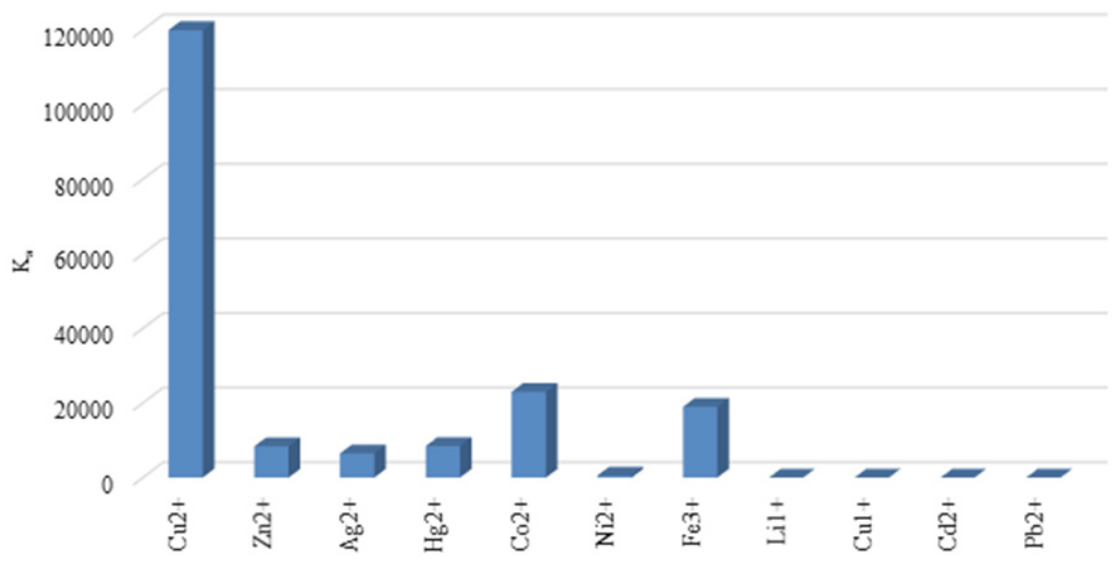

Fig. 3: Fluorescence selectivity of 5 toward $\mathrm{Cu}^{2+}$ over various competitve ions<smiles>COC(=O)C(C)N=Cc1ccc(O)cc1</smiles>

Fig. 4: The structure of Schiff base moiety, 6 $\mathrm{g}(3.11 \mathrm{mmol})$ dissolved in acetonitrile $(50 \mathrm{~mL})$, and the solution was stirred for 60 hours were refluxed. After cooling, the solvent evaporated under vacuum. The residue solid was extracted with $\mathrm{CH}_{2} \mathrm{Cl}_{2}(100$ $\mathrm{mL})$ and rinsed off with water $(50 \mathrm{~mL})$ and $1 \mathrm{M} \mathrm{HCl}$ $(2 \times 50 \mathrm{~mL})$. Then the organic layer was dried over $\mathrm{MgSO}_{4}$ and crystallized from $\mathrm{CH}_{2} \mathrm{Cl}_{2}$ : methanol (1:1). Yield $0.84 \mathrm{~g}(85 \%)$ 4. $T_{\mathrm{mp}} .: 211-213{ }^{\circ} \mathrm{C} ; \mathrm{IR}, \mathrm{v}, \mathrm{cm}^{-1}$ : $1667(\mathrm{C}=\mathrm{O}) ;{ }^{1} \mathrm{H}$ NMR, $\delta$, ppm: $\delta=0.93 \mathrm{t}\left(6 \mathrm{H}, \mathrm{CH}_{3}\right)$, $1.02 \mathrm{~s}\left(18 \mathrm{H},-\mathrm{C}\left(\mathrm{CH}_{3}\right)_{3}\right), 1.05 \mathrm{~s}\left(9 \mathrm{H},-\mathrm{C}\left(\mathrm{CH}_{3}\right)_{3}\right), 1.2$ $\mathrm{s}\left(9 \mathrm{H},-\mathrm{C}\left(\mathrm{CH}_{3}\right)_{3}\right), 1.3 \mathrm{t}\left(3 \mathrm{H}, \mathrm{CH}_{3}\right), 2.01-2.07 \mathrm{~m}(6 \mathrm{H}$, $\left.-\mathrm{OCH}_{2}-\mathrm{CH}_{2}-\mathrm{CH}_{3}-\right), 2.67 \mathrm{~m}\left(2 \mathrm{H},-\mathrm{OCH}_{2}-\mathrm{CH}_{2}-\mathrm{CH}_{2} \mathrm{O}-\right)$, $3.18 \mathrm{~d}\left(4 \mathrm{H}, \mathrm{J}=12.5 \mathrm{~Hz}, \mathrm{ArCH}_{2} \mathrm{Ar}\right), 3.82 \mathrm{t}(4 \mathrm{H}$, 
$\left.-\mathrm{OCH}_{2}-\mathrm{CH}_{2}-\mathrm{CH}_{2}-\right), 3.93 \mathrm{t}\left(2 \mathrm{H},-\mathrm{OCH}_{2}\right), 4.15 \mathrm{t}(2 \mathrm{H}$, $\left.-\mathrm{OCH}_{2}\right), 4.31 \mathrm{t}\left(2 \mathrm{H},-\mathrm{OCH}_{2}\right), 4.35 \mathrm{~d}(4 \mathrm{H}, 2 \mathrm{~J}=12.5$ $\left.\mathrm{Hz}, \mathrm{ArCH}_{2} \mathrm{Ar}\right), 6.74 \mathrm{~d}(4 \mathrm{H}, \mathrm{J}=2.0 \mathrm{~Hz}, \mathrm{ArH}), 6.92 \mathrm{~s}$ $(4 \mathrm{H}, \mathrm{ArH}), 7.08 \mathrm{~d}(2 \mathrm{H}, \mathrm{J}=2.0 \mathrm{~Hz}, \mathrm{ArH}), 7.89 \mathrm{~d}(2 \mathrm{~J}=$ $11.9 \mathrm{~Hz}, 2 \mathrm{H}, \mathrm{ArH}), 9.94 \mathrm{~s}(\mathrm{H}, \mathrm{CHO}) ;{ }^{13} \mathrm{C} \mathrm{NMR}(125$ $\mathrm{MHz}) \delta=10.71,10.85,23.69,23.82,30.37,31.47$, $31.50,31.80,31.95,31.98,34.17,34.30,66.61$, 72.08, 72.21, 77.72, 115.14, 125.15, 125.32, 125.47, $125.59,132.43,133.55,133.76,134.71,144.63$,
144.75, 145.19, 153.70, 164.71, 191.21; HRMS m/ $Z=(951.47)[\mathrm{M}]^{+}$

25,26,27-Tripropoxy-28-[(3-[(methyl 2-(benzyliden amino) propanoate)]propoxy)]-5,11,17,23 tetra(tertbutyl)calix[4]arene $\left(5, \mathrm{C}_{67} \mathrm{H}_{91} \mathrm{NO}_{7}\right)$

A solution of L-Alanine methyl ester hydrochloride $0.04 \mathrm{~g}(0.37 \mathrm{mmol})$ and triethylamine (1 $\mathrm{mL}$, excess) in $\mathrm{MeOH}(10 \mathrm{~mL})$ were added to solution
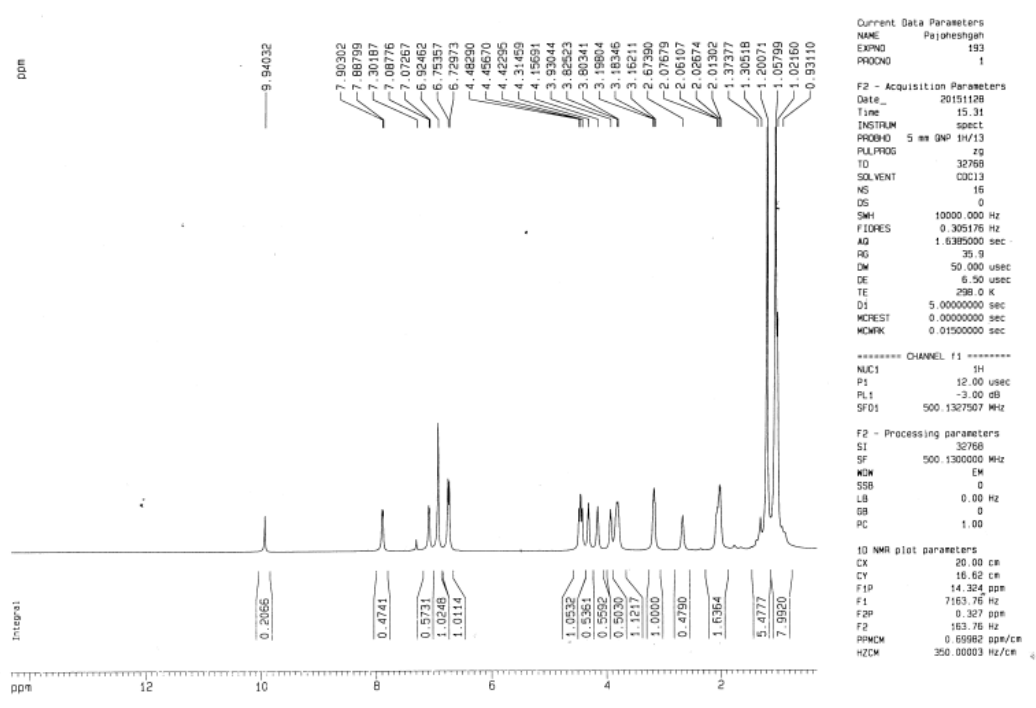

Fig. S1: $\left.{ }^{1} \mathrm{H} \mathrm{NMR} \mathrm{(500.1} \mathrm{MHz,} \mathrm{CDCl}_{3}\right)$ spectrum of 4

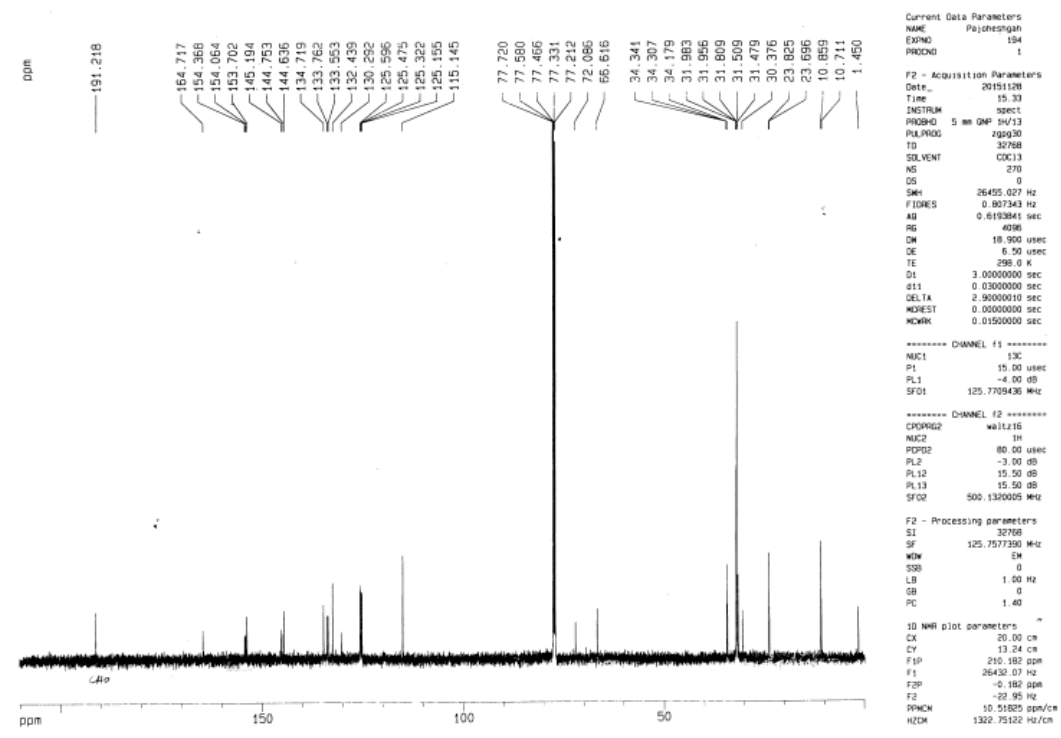

Fig. S2: ${ }^{13} \mathrm{C}$ NMR (125 MHz, $\mathrm{CDCl}_{3}$ ) spectrum of 4 
of compound $40.2 \mathrm{~g}(0.37 \mathrm{mmol})$ in $\mathrm{CHCl}_{3}(50 \mathrm{~mL})$ and the reaction mixture was refluxed for 2 days. After cooling the crude material was crystallized from $\mathrm{CHCl}_{3}: \mathrm{MeOH}(1: 3)$. Yield 0.7g (71\%) 5. $\mathrm{T}_{\mathrm{mp}}:: 110-114$ ${ }^{\circ} \mathrm{C} \mathrm{IR}, v, \mathrm{~cm}^{-1}: 1750(\mathrm{C}=\mathrm{O}) ;{ }^{1} \mathrm{H}$ NMR, $\delta, \mathrm{ppm}$ : $\delta=1.02$ $\mathrm{s}\left(9 \mathrm{H},-\mathrm{C}\left(\mathrm{CH}_{3}\right)_{3}\right), \delta=1.04 \mathrm{~s}\left(18 \mathrm{H},-\mathrm{C}\left(\mathrm{CH}_{3}\right)_{3}\right), 1.05-1.12$ $\mathrm{m}\left(18 \mathrm{H},-\mathrm{C}\left(\mathrm{CH}_{3}\right)_{3}\right.$ and $\left.\left.\mathrm{CH}_{3}\right)\right), 1.22 \mathrm{~d}\left(3 \mathrm{H}, \mathrm{CH}_{3}\right), 1.55$ $\mathrm{m}\left(6 \mathrm{H},-\mathrm{OCH}_{2}-\mathrm{CH}_{2}-\mathrm{CH}_{3}-\right), 2.07 \mathrm{~m}\left(2 \mathrm{H},-\mathrm{OCH}_{2}-\mathrm{CH}_{2}-\right.$ $\left.\mathrm{CH}_{2} \mathrm{O}-\right), 3.14 \mathrm{~d}\left(4 \mathrm{H}, \mathrm{J}=12.3 \mathrm{~Hz}, \mathrm{ArCH}_{2} \mathrm{Ar}\right), 3.72-4.05$ m (14H, $\left.-\mathrm{OCH}_{2}-\mathrm{CH}_{2}-\mathrm{CH}_{2}-, \mathrm{OCH}_{3}, \mathrm{CH}-\mathrm{CH}_{3}\right), 4.40 \mathrm{~d}$ $\left(4 \mathrm{H}, 2 \mathrm{~J}=12.3 \mathrm{~Hz}, \mathrm{ArCH}_{2} \mathrm{Ar}\right), 6.68-6.94 \mathrm{~m}(13 \mathrm{H}, \mathrm{ArH}$ and $\mathrm{CH}) ; \mathrm{HRMS} \mathrm{m} / \mathrm{z}=(1055.6644)[\mathrm{M}]^{+}$

\section{RESULTS AND DISCUSSION}

In this work we synthesized new chiral Schiff base calix[4]arene and also investigated identification properties of it towards different metal ions. The synthesis of 5 is depicted in Figure 1.

To prepare the $4, p$-hydroxybenzaldehyde was added to 3 in $\mathrm{CH}_{3} \mathrm{CN}$ in presence of $\mathrm{K}_{2} \mathrm{CO}_{3}$ as a base. Compound 4 was characterized by a combination of FT-IR, ${ }^{1} \mathrm{H}$ NMR and HRMS. The spectral data of $\mathbf{5}$ could be found in the experimental

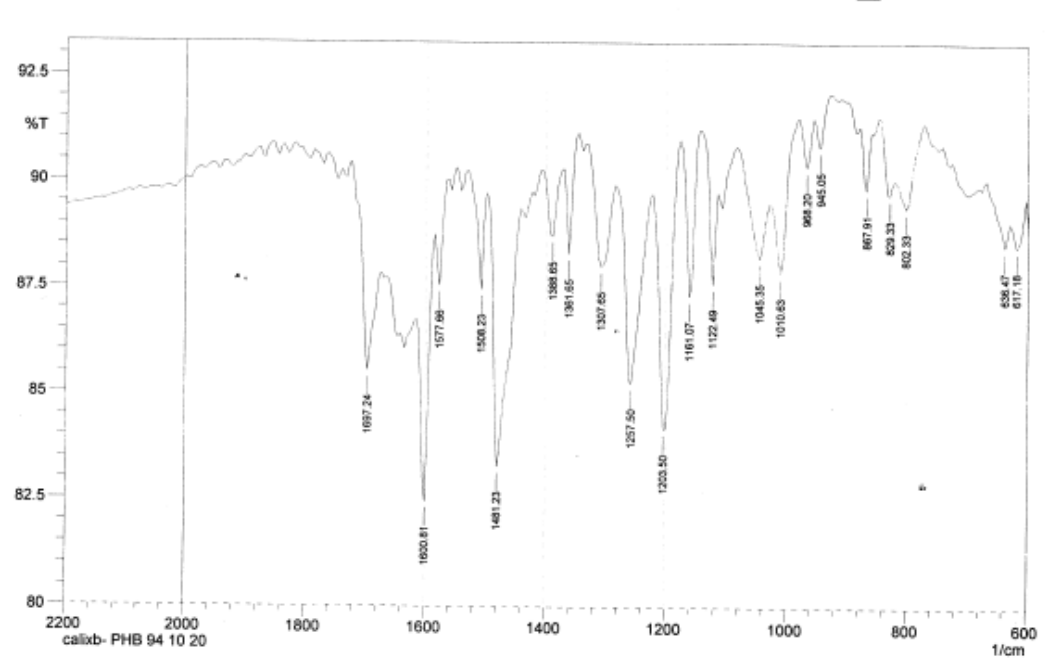

Fig. S3: FT-IR spectrum of 4

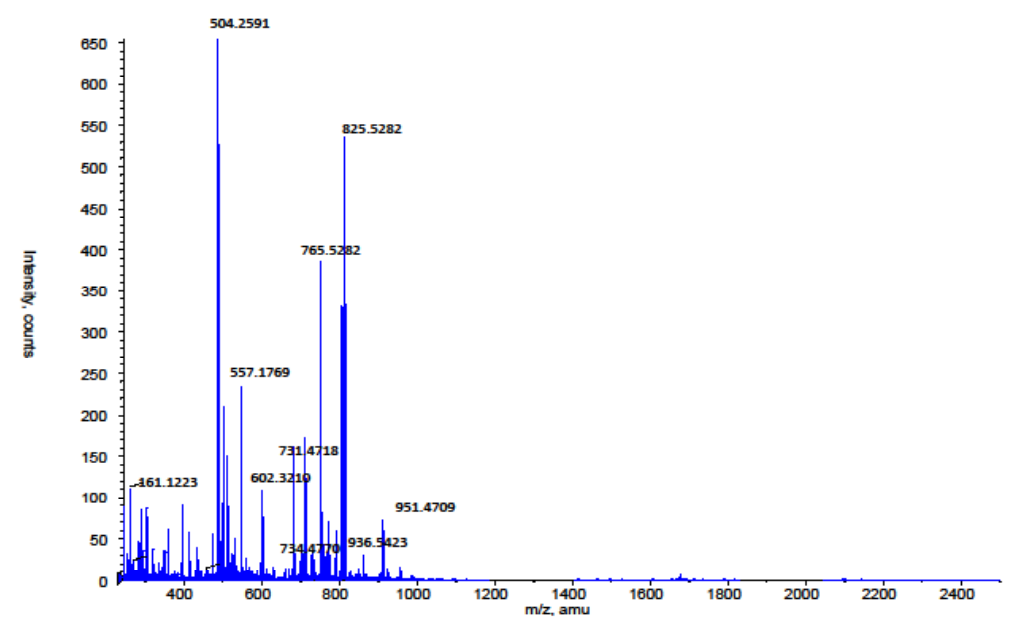

Fig. S4: High-resolution mass spectrum (HRMS) of 4 

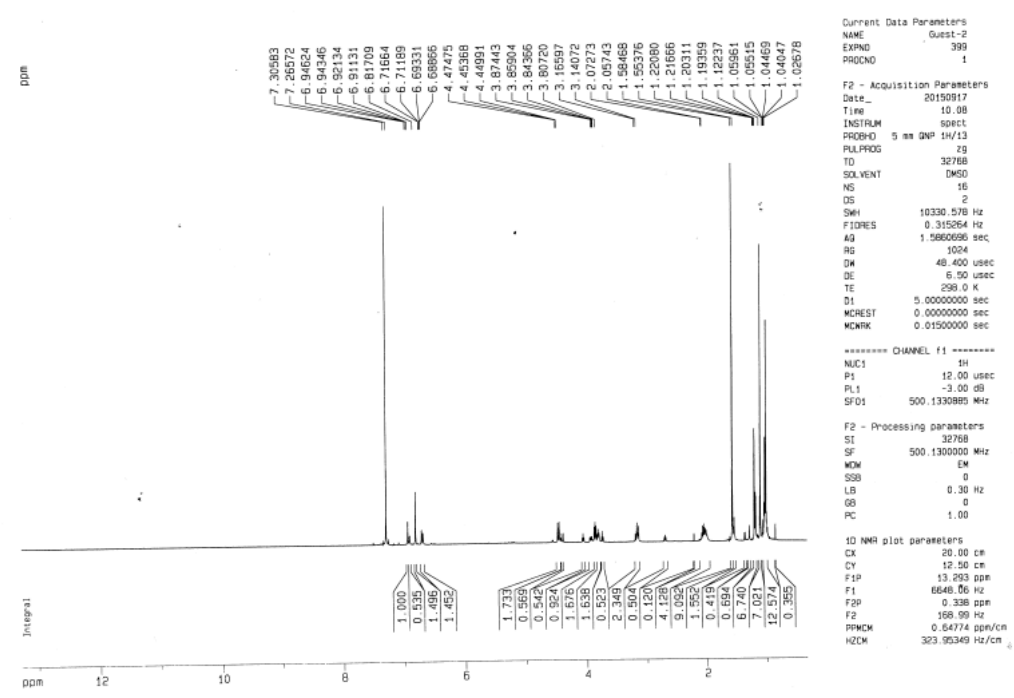

Fig. S5: ${ }^{1} \mathrm{H}$ NMR $\left(500.1 \mathrm{MHz}, \mathrm{CDCl}_{3}\right)$ spectrum of 5

section. Compound $\mathbf{5}$ is asymmetric because of the connection of amino acid as a chiral subunits in the calix[4]arene.

Selectivity and sensitivity of the synthesized receptor $\mathbf{5}$ were studied by using fluorescence titration experiments in $\mathrm{CH}_{3} \mathrm{CN}$ solution. The Data analysis and $K_{a}$ values were determined by Sigmaplot-software. Our results show that receptor 5 can be served as a selective metal sensors. Figure 3 illustrates how adding a number of metal ions can change the fluorescence intensity of molecular receptor 5 relatively. From this data, it can be observed that whereas no remarkable change occurs by adding number of metal ions, $\mathrm{Cu}^{2+}$ generates a significant quenching on its emission band. This could be applied as a fluorescence sensor which needed a complete investigation of 5 through fluorescence spectroscopy when different ions are present. ûuorescence emission spectrum of $\mathbf{5}$ was recorded from 300 to $550 \mathrm{~nm}$ by exciting it at 290 $\mathrm{nm}$ when the emission maximum was recorded at $330 \mathrm{~nm}$.

\footnotetext{
Binding constants $\left(K_{a}\right)$ were calculated by equation based on literature ${ }^{15}$.
}

The fluorescence intensity of $\mathbf{5}$ in the presence increasing concentration of $\mathrm{Cu}^{2+}$ is shown in Figure2. According to our fluorescence spectral studies the association constant between 5 and $\mathrm{Cu}^{2+}$ was $1.2 \times 10^{5} \mathrm{M}^{-1}$.

More over, In order to understand the selectivity $\mathrm{Cu}^{2+}$ by the receptor, comparative cations fluorescence measurements were done with different cations. It has been found that $\mathrm{Cu}^{2+}$ does confer significant change in the fluorescence measurements. (Figure 3)

The Job's plot studies show a 1:1 stoichiometry between (5) and $\mathrm{Cu}^{2+}$ ion.

In order to examine the interaction between Schiff base moiety 6 (Figure 4) and different ions metal, this compound was prepared based on the literature methods ${ }^{16}$. Our results show that only the Schiff base moiety has no interaction with the metal ions.

\section{ACKNOWLEDGEMENTS}

Partial financial support by Chemistry and Chemical Engineering Research Center of Iran is greatly appreciated. 

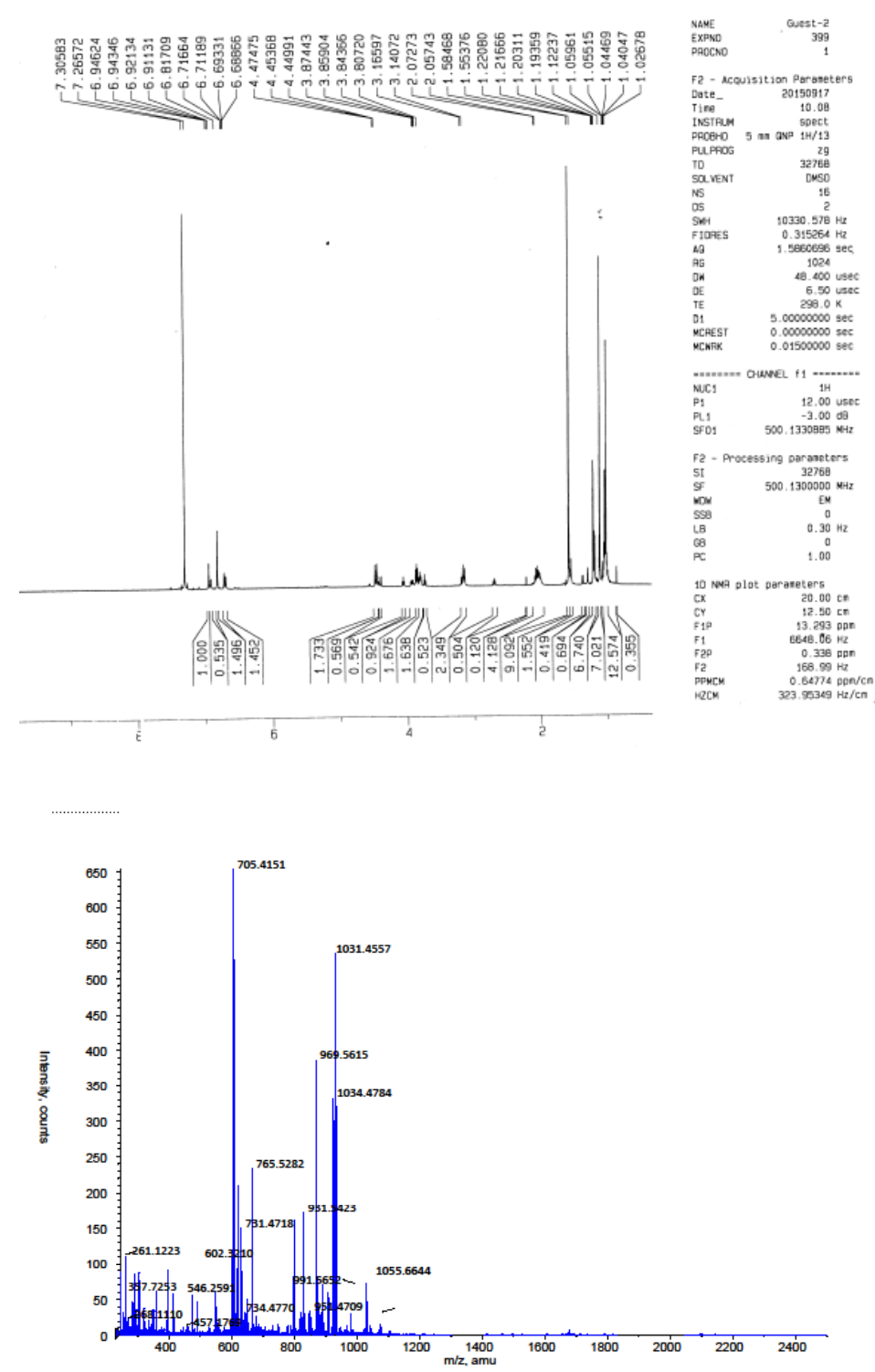

Fig. S6: High-resolution mass spectrum (HRMS) of 5

\section{REFERENCES}

1. Chawla, H.M.; Pant, N.; Kumar, S.; Kumar, N.; Black david, St.C. Calixarene-based materials for chemical sensors. In: Korotcenkov, G., (Eds.), Chemical Sensors: Fundamentals of Sensing Materials. Polymers and other materials. Momentum Press, 2010, 3, pp. 300, New York.

2. Kumar, A.; Kumar, V.; Upadhyay, K.K.; Roychowdhury, P.K.J. J. Mol. Struct. 2013,
1035, 174-182.

3. Kim, H.J.; Kim, S.H.; Anh, L.N.; Lee, J.H.; Lee, C.; Kim, J.S. Tetrahedron Lett. 2009, 50, 2782-2786.

4. de Silva, A.P.; Fox, D.B.; Huxley, A.J.M.; Moody, T.S. Coord. Chem. Rev. 2000, 205, 41-57.

5. Que, E.L.; Domaille, D.W.; Chang, C.J. Chem. Rev. 2008, 108, 1517-1549. 
6. Gaggelli, E.; Kozlowski, H.; Valensin, D.; Valensin, G. Chem. Rev. 2006, 106, 19952044.

7. Schaferling, M. Angew. Chem. Int. Ed. 2012, 51, 3532-3554.

8. Chawla, H.M.; Hundal, G.; Singh, S.P.; Upreti, S. CrystEngComm. 2007, 9, 119-122.

9. Gutsche, C.D. Calixarenes: Monographs in Supramolecular Chemistry, in: Stoddart, J.F. (Eds), Edu. Div. RSC. 1989, London.

10. Chawla, H.M.; Shukla, R.; Pandey, S. Tetrahedron Lett. 2012, 53, 2996-2999.

11. Xu, V.; meng, J.; Meng, L.; Dang, Y.; Cheng, Y.; Zhu, C. Chem. Eur. J. 2010, 16, 1289812903.
12. Hsieh, W.H.; Wan, C.F.; Liao, D.J.; Wu, A.T. Tetrahedron Lett. 2012, 53, 5848-5851.

13. Gutsche, C.D.; Iqbal, M.; Stewart, D. J. Org. Chem. 1986, 51, 742-745.

14. Iwamoto, K.; Araki, K.; Shikai, S. J. Org. Chem. 1991, 56, 4955-4962.

15. Inoue, Y.; Yamamoto, K.; Wada, T.; Everitt, S.; Gao, X.M.; Hou, Z.J.; Tong, L.H.; Jiang, S.K.; Wu, H.M. J. Chem. Soc. Perkin Trans. 2. 1998, 1807-1816.

16. Dios, A.; Mitchell, R.A.; Aljabari, B.; Jodi, L.; O‘Connor, K.A.; Liao, H.; Senter, P.D.; Manogue, K.R.; Lolis, E.; Metz, C.; Bucala, R.; Callaway, D.J.E.; Al-Abed, Y. J. Med. Chem. 2002, 45, 2410-2416. 